\title{
Vertical distribution of epiphytic bryophytes in Atlantic Forest fragments in northeastern Brazil
}

\author{
Hermeson Cassiano de Oliveira $^{{ }^{*}}$ and Sylvia Mota de Oliveira ${ }^{2}$
}

Received: August 18, 2016

Accepted: October 21, 2016

\begin{abstract}
The microclimatic gradient established from the forest understory to the canopy provides a range of different conditions for the establishment of bryophytes along the height of a tree. We investigated epiphytic bryophyte communities of four fragments of Atlantic Forest with the aim of describing their vertical zonation and assessing differentiation among the communities of the different fragments. In each fragment, five host trees were selected from which bryophyte samples were collected in four height zones from the base to the canopy. Furthermore, 10 plots were demarcated in each fragment where bryophytes were collected from the understory. In total, 114 bryophyte species were found on the 20 sampled phorophytes, plus an additional 51 species in the understory, for a total of 165 species. Species composition of height zones differed significantly between communities of the trunk base and the canopy. The samples from the understory included $77 \%$ of all species. Among all species found, 10 showed a significant preference for a specific height. Around $70 \%$ of the bryophyte species grew as mats; this life form occurred in all trees and height zones. The results showed a weak, yet significant, vertical gradient, which differs from what is usually found in the Atlantic Forest.
\end{abstract}

Keywords: canopy, ecology, liverworts, mosses, tropical rain forest

\section{Introduction}

In tropical forests, the epiphytic habit is clearly the most important for bryophytes, where communities colonize trees from the base to the outermost canopy twigs (Richards 1984). This pattern of colonization is facilitated by the elevated moisture in tropical environments, which provides ideal microclimatic conditions for the development of these plants (Frahm 2003). The variety of microhabitats and the constantly moist microclimates facilitate the cooccurrence of numerous species, which results in high species diversity (Gradstein et al. 2008).

The microclimatic gradient from the forest understory to the canopy, with significant variation in air temperature, relative humidity, light availability and $\mathrm{CO} 2$ concentration, is well documented in the literature (Whitmore 1998; Lowman \& Rinker 2004). A clear turnover in bryophyte species composition along this vertical gradient on host trees has been documented in tropical rainforest sites (Sporn et al. 2010). In the Guianas, species turnover along the vertical gradient has been shown to be consistent accross local as well as regional scales, with data from three different localities following the same pattern (Cornelissen \& Steege 1989; Oliveira et al. 2009).

Studies dealing with vertical zonation of bryophytes in the Atlantic Forest have found little differentiation between understory and canopy, since a significant turnover in bryophyte species composition was not present, which can

\footnotetext{
${ }^{1}$ Universidade Estadual do Piauí, Campus Heróis do Jenipapo, 64280-000, Campo Maior, PI, Brazil

${ }^{2}$ Naturalis Biodiversity Center, Einsteinweg 2, 2333 CC, Leiden, The Netherlands

*Corresponding author: hermeson123@gmail.com
} 
be a consequence of the altered microclimatic conditions in fragmented forests (Germano 2003; Campelo \& Pôrto 2007; Silva \& Pôrto 2013). The closed canopy of undisturbed forests is more favorable to vertical species turnover of epiphytes, because microenvironmental conditions are clearly distinct (Werneck \& Espírito-Santo 2002).

Epiphytic bryophytes with different life forms and with different water conduction and retention structures could be indicators of the height zone where they occurr due to their potential strict reliance on a particular level of water supply, gas exchange and light availability (Proctor 1990). The strong correlation of life forms with moisture and light conditions has been extensively discussed (Thiers 1988; Sporn et al. 2010), however, there have been few studies of these patterns in the Atlantic Forest. According to Gimingham \& Birse (1957), cushions, mats and turf can be roughly considered as xeric life forms with increasing drought-tolerance, whereas dendroids, fans, pendants, and wefts are life forms characteristic of wet environments.

In this work, we investigated the epiphytic bryophyte communities of four fragments of Atlantic Forest that belong to the same forest matrix, with the aim of assessing their vertical zonation and the relationship between canopy and understory. We also evaluated species richness and composition among the studied fragments.

\section{Materials and methods}

\section{Study area}

The study was carried out in the Ecological Reserve Michelin, property of Plantações Michelin da Bahia LTDA, in the municipalities of Igrapiúna and Ituberá (13 $48^{\prime} 08^{\prime \prime} \mathrm{S}$, $39^{\circ} 10^{\prime} 03^{\prime \prime} \mathrm{W}$ ) in Bahia State, Brazil (Fig. 1). The total area of the reserve is 3,096 ha and includes a range of environments that are part of the Atlantic Forest biome, such as restinga, mangrove and estuary, besides the main tropical rainforest matrix. The region has a humid tropical climate (Af) with an average annual precipitation of 2,051 $\mathrm{mm}$, which is distributed throughout the year. The average temperature varies between $18{ }^{\circ} \mathrm{C}$ and $30^{\circ} \mathrm{C}$ (CEI/CONDER 1993). The forest is classified as a Lowland Tropical Rainforest and its altitude varies from sea level to $327 \mathrm{~m}$ (Veloso et al. 1991).

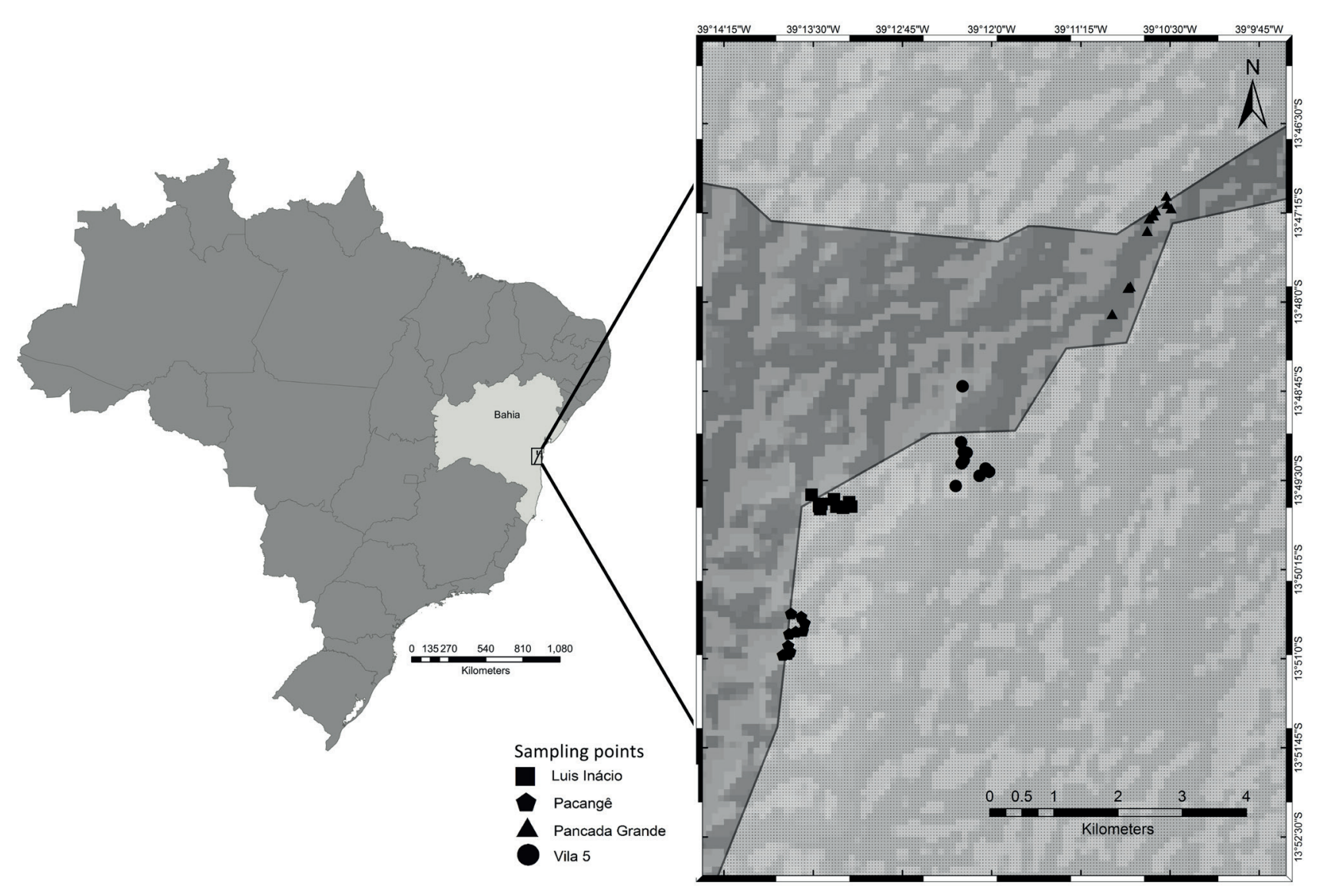

Figure 1. Location of the Michelin Ecological Reserve in the state of Bahia, Brazil, with the sampling points indicated. 


\section{Sampling design}

Bryophyte sampling took place in four forest fragments within this complex: Mata de Pacangê (PAC) - 550 ha; Mata da Vila Cinco (MV) - 180 ha; Mata de Pancada Grande (PG) - 172 ha; and Mata do Luis Inácio (LI) - 140 ha, with a total forest cover of 1,042 ha. In each of the four fragments, five canopy trees were selected, considering size for climbing and bryophyte cover, that were separated from each other by at least $100 \mathrm{~m}$, for a total of 20 trees. Four height zones were established to standardize sampling of vertical zonation, following Pócs (1982). Samples were collected in each height zone of all selected trees, which ammounted to 80 sample units (20 trees $x 4$ zones). Additionally, 10 plots of $100 \mathrm{~m}^{2}$ were established in each forest fragment, where understory bryophytes were sampled from the stems of five young trees of CAP $>0.30<1.0 \mathrm{~m}$, up to a maximum of $2 \mathrm{~m}$ high, and from leaves of shrubs or young trees (Gradstein et al. 1996).

\section{Plant Material}

Samples were identified to species level using identification keys, illustrations and descriptions from specialized literature (Florschütz 1964; Fulford 1963, 1966, 1968, 1976; Sharp et al. 1994; Buck 1998; Dauphin 2003; Gradstein \& Costa 2003). The classification system used was Crandall-Stotler et al. (2009) for liverworts and Goffinet et al. (2009) for mosses. After observation and identification, the samples were deposited in the Herbarium ALCB of the Federal University of Bahia.

To verify changes in life forms and water conduction and retention structures, six life forms were recorded following the classification of Frahm (2003): cushion, dendroid, mat, pendent, turf and weft. Presence/absence of seven morphological adaptations related to water conduction/ retention (Glime 2007) were also recorded: long acuminate or piliferous apex, lobules, concave leaves, hyalocysts, tomentose gametophyte, allar cells and papillae.

\section{Data analysis}

Species accumulation curves were built using bulk samples of all height zones of each tree, with host tree as surrogate unit of area. We used Analysis of Variance (ANOVA) to test for differences in species richness between height zones in the data subset from the canopy trees $(\mathrm{N}=80)$, as well as to test for differences in species richness between fragments in the complete data set $(\mathrm{N}=120)$. Furthermore, we performed a Kolmogorov-Smirnov Analysis of Similarities (ANOSIM) with all sample pairs of the complete dataset to detect significant differences in species composition between fragments.

In order to identify intrinsic gradients in community composition, we carried out Detrended Correspondence
Analysis (DCA), an indirect ordination method (solely based on species composition of communities) which assumes that species show an unimodal response along the gradient (McCune \& Grace 2002). The ordination was carried out for the dataset obtained from canopy host trees, first with all fragments and then by fragment. After visual inspection including sample labels, such as height zone, elevation and spatial location (fragment), correlation between the axis and height zone was tested for significance through permutation procedure, since grouping of samples were only detected for height zone. All analyses were performed in R 2.14.1 (R Core Team 2012).

Indicator Species Analysis (ISA, McCune \& Grace 2002) was carried out to explore species preference for a specific height zone on host trees and for a given fragment. Indicator species of zones 1 and 2 were classified as understory specialists; indicators species of zones 3 and 4 were classified as canopy specialists. In order to score the occurrence of the life forms and morphological features per height zone, the percentage of occurrence per zone relative to the percentage of incidence of the life form/morphological feature in the species list was used.

\section{Results}

A total of 114 bryophyte species were found on the 20 sampled phorophytes, of which 76 belonged to Marchantiophyta (liverworts), distributed among six families and 24 genera, and 38 to Bryophyta (mosses), distributed among 11 families and 21 genera. Including samples from small trees of the understory, the total number of species recorded increases to 165, with 62 moss species belong to 16 families and 32 genera and 103 liverwort species belong to eight families and 30 genera (Tab. S1 in supplementary material). Among the liverworts, Lejeuneaceae was the most represented family with 71 species, while Aneuraceae was the least represented with only one species. Among the mosses, Calymperaceae was the most represented family with 16 especies, while Bryaceae, Fissidentaceae, Hypnaceae and Stereophyllaceae had only one species each. Species accumulation curves (species host tree) show that a sample of ten trees is sufficient to capture $75 \%$ of the number of species that are captured when the number of sampled trees is doubled (i.e., the total of 20 trees; Fig. 2).

Species richness did not vary significantly either among fragments, with 89 species on average, or among height zones $(P>0.05)$. Average number of species per host tree was also similar among fragments (Fig. 3). The greatest similarities in species composition among height zones were found between adjacent zones, and decreased with increasing distance between zones (Tab. 1).

The DCA analysis of the 114 bryophyte species produced three primary axes with eigenvalues of $0.73,0.63$ and 0.44 . Axis I explained $41 \%$ of the variation and axis II $14.38 \%$ 


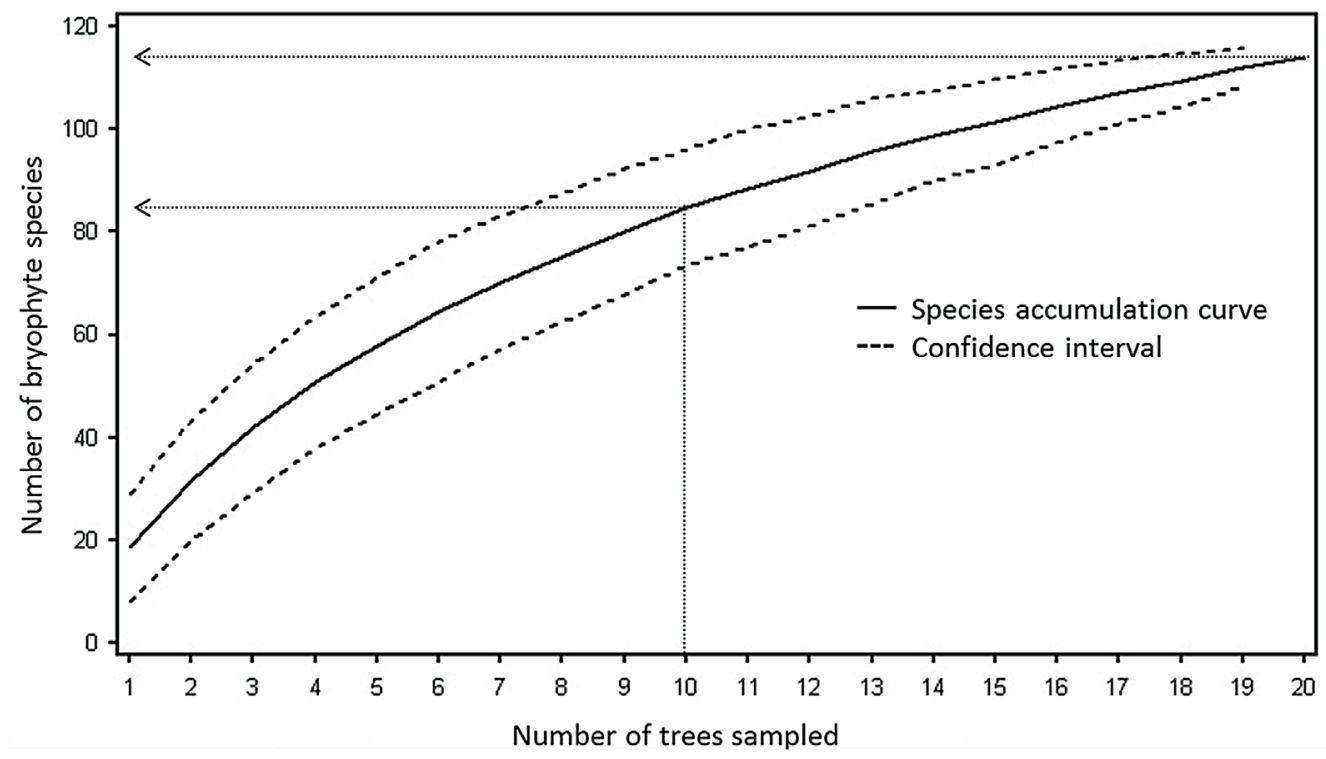

Figure 2. Randomized species phorophyte curve for the 114 species found in 20 trees sampled, showing that only half of the effort is needed to sample $75 \%$ of the species found in 20 trees.

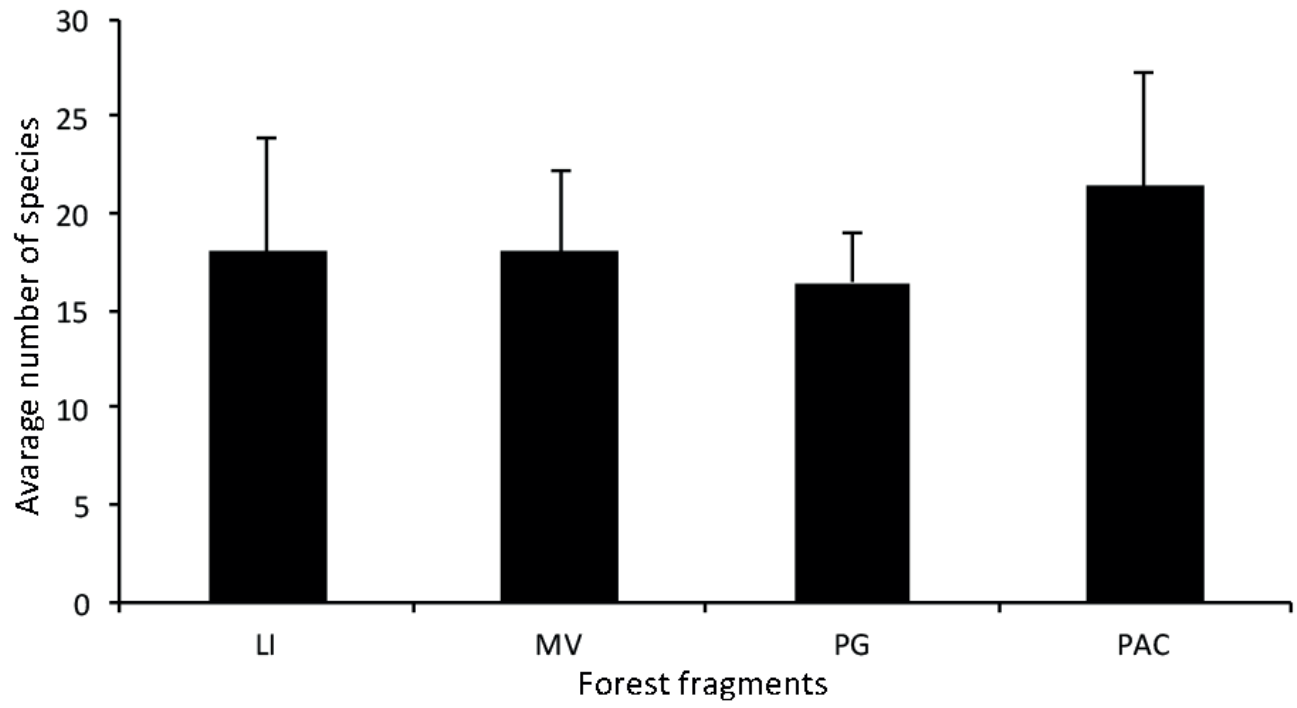

Figure 3. Average number and standard deviation of epiphytic bryophyte species per host tree in each of the four forest fragments.

Table 1. Sørensen index and number of species shared for each pair of height zones, including samples from the base of understory trees (UN).

\begin{tabular}{|c|c|c|c|c|c|}
\hline & UN & Z1 & Z2 & Z3 & Z4 \\
\hline & & \multicolumn{4}{c|}{ Number of species shared } \\
\hline UN & - & 53 & 38 & 41 & 37 \\
\hline Z1 & 0.55 & - & 33 & 29 & 25 \\
\hline Z2 & 0.33 & 0.45 & - & 34 & 28 \\
\hline Z3 & 0.29 & 0.42 & 0.63 & - & 36 \\
\hline Z4 & 0.26 & $0.33 \quad$ Sørensen index & \\
\hline
\end{tabular}


(Fig. 4). On the first axis, sample units from heigh zones 1 and 4 were clearly separated, while zones 2 and 3 exhibited overlap. Pearson correlation of the scores of the first axis for the DCA and height zone was significant $(\mathrm{P}<0.001)$ after permutation test. None of the explanatory variables we measured could be correlated with axis II or III. When the same analysis was applied for fragments separetely, only Pacangê showed a slightly, yet significant, correlation $(\mathrm{P}<0.01)$ between axis I scores and height zones, where axis I had an eigenvalue of 0.56 and explained $91 \%$ of the variation (Fig. 5).
Among the 114 species recorded, 10 showed significative preferences for a given height zone $(\mathrm{P}<0.05)$, according to the Indicator Species Analysis (ISA). Most of these species, here classified as specialists, were found at the extremes of the gradient: Calymperes lonchophyllum, Plagiochila aerea, Prionolejeunea scaberula and Taxithelium planum were indicator species of zone 1 and Cheilolejeunea trifaria, Cheilolejeunea xanthocarpa, Frullania caulisequa and Groutiella apiculata were indicator species of zone 4. Ceratolejeunea rubiginosa and Ceratolejeunea fallax were indicators of zones 2 and 3, respectively (Fig. 6).

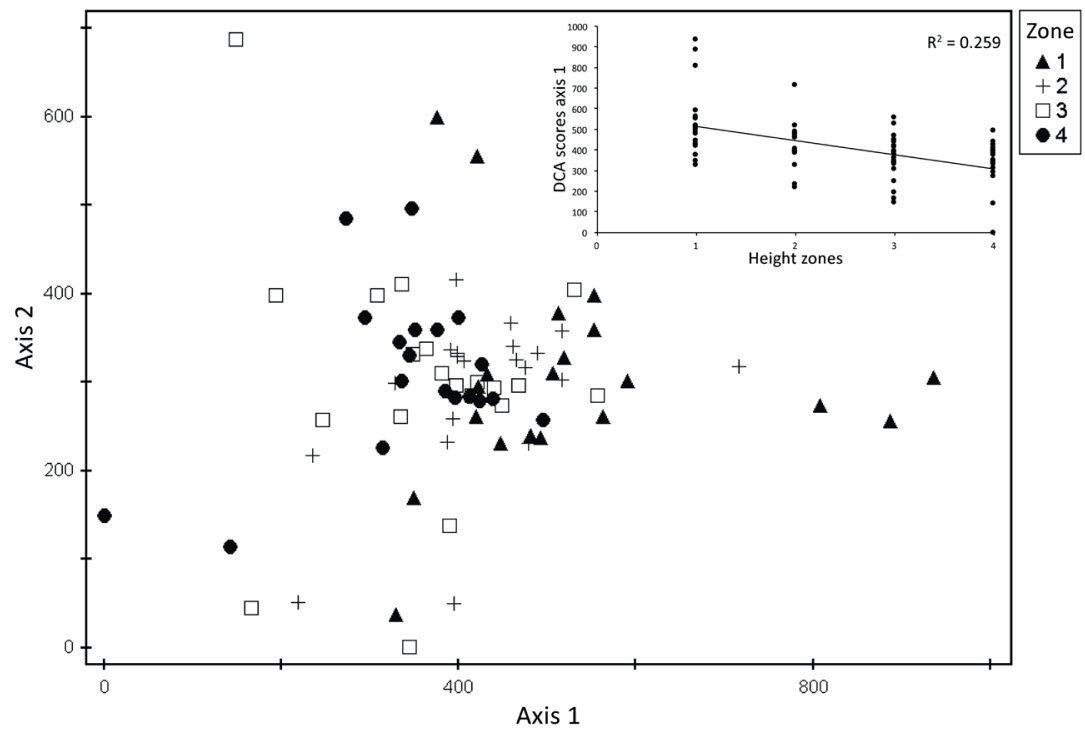

Figure 4. Scatterplot showing first and second axes of DCA of 114 species of epiphytic bryophytes in different height zones in the studied fragments. Height zone to which the plot belongs are as follows: triangles = zone 1; plus sign = zone 2; squares = zone 3; circles = zone 4. Eigenvalues were 0.73 (Axis 1), 0.63 (Axis 2). Top right corner: correlation between height zones and DCA values (Axis $1 ; \mathrm{P}=0.0000008$ ).

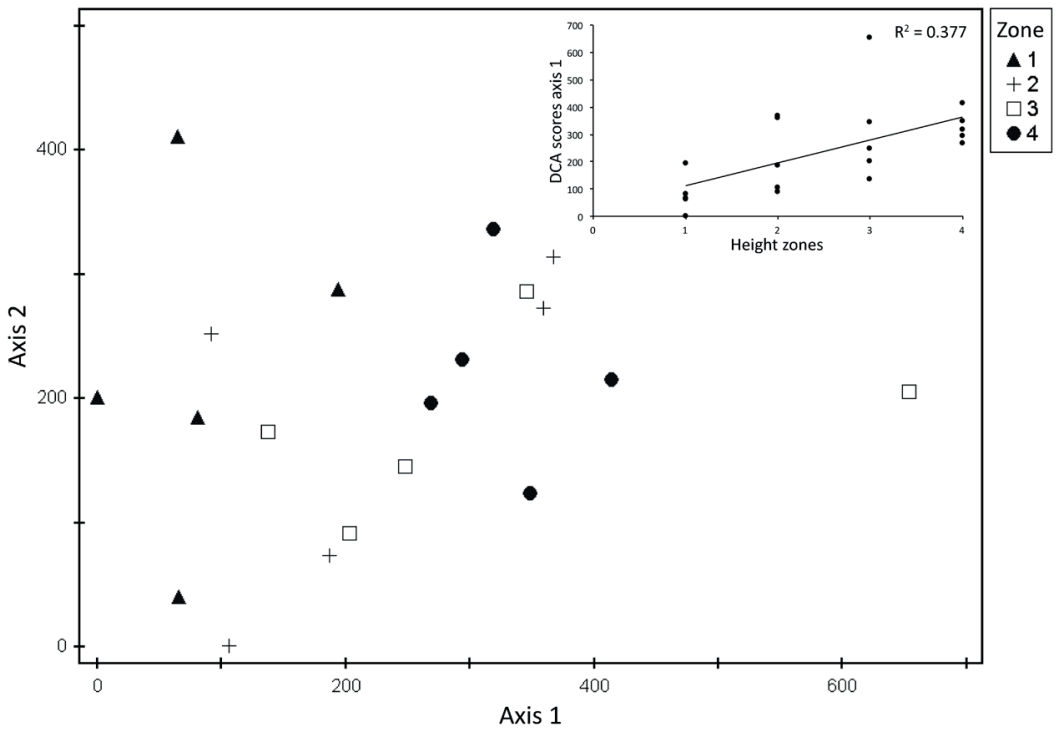

Figure 5. Scatterplot showing first and second axes of DCA of 54 species of epiphytic bryophytes in different height zones in Pacangê fragment. Height zone to which the plot belongs are as follows: triangles = zone 1; plus sign = zone 2; squares = zone 3; circles = zone 4. Eigenvalues were 0.74 (Axis 1) and 0.47 (Axis 2). Top right corner: correlation between height zones and the DCA values (Axis 1 ) in Pacangê fragment $(\mathrm{P}=0.003)$. 
Plagiochila aerea
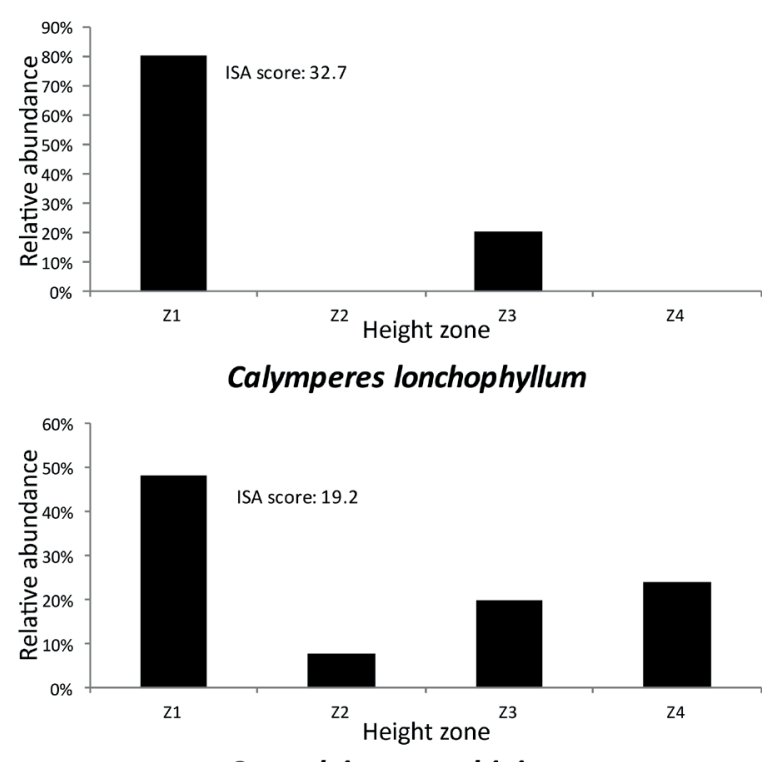

Ceratolejeunea rubiginosa
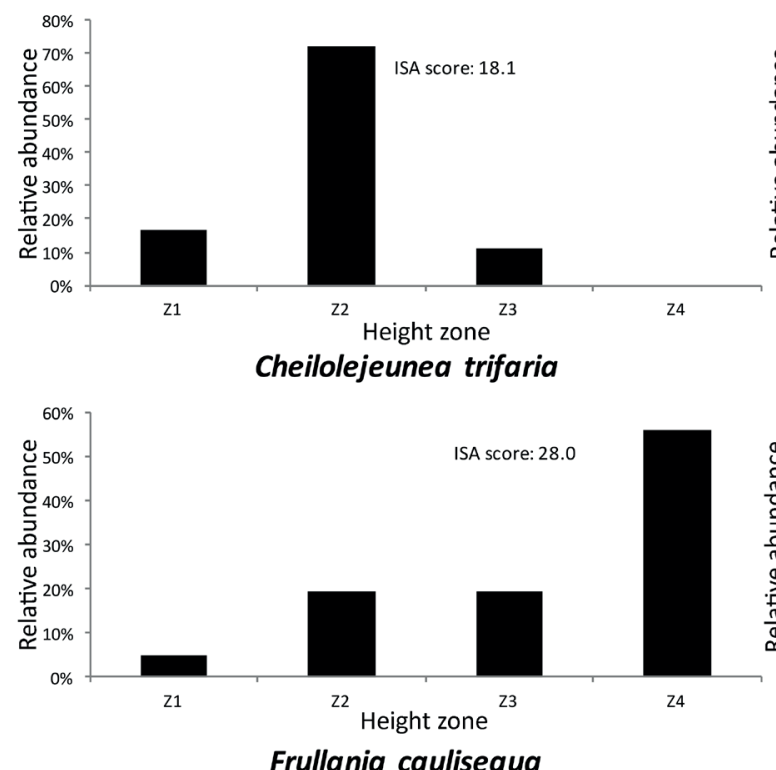

Frullania caulisequa

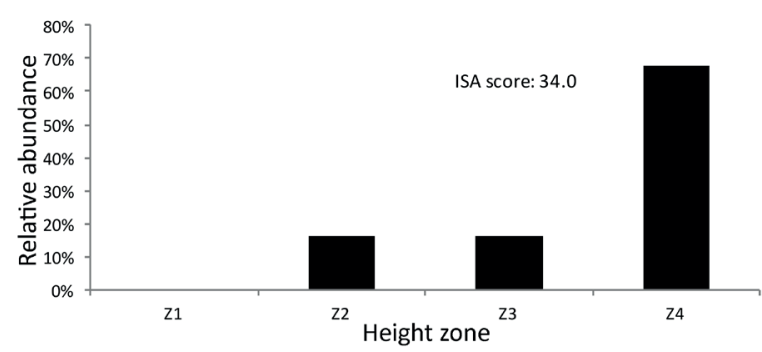

Prionolejeunea scaberula
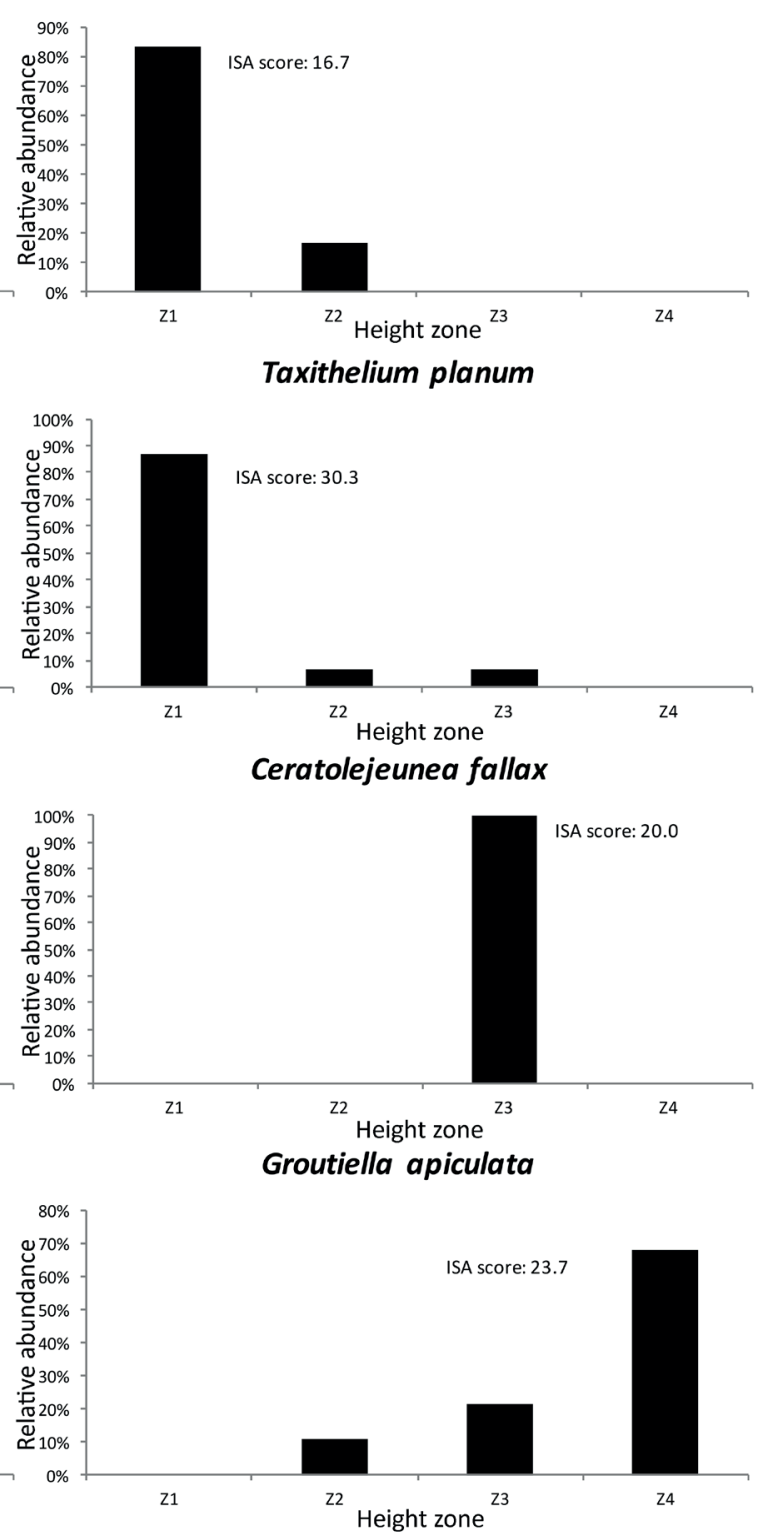

Cheilolejeunea xanthocarpa

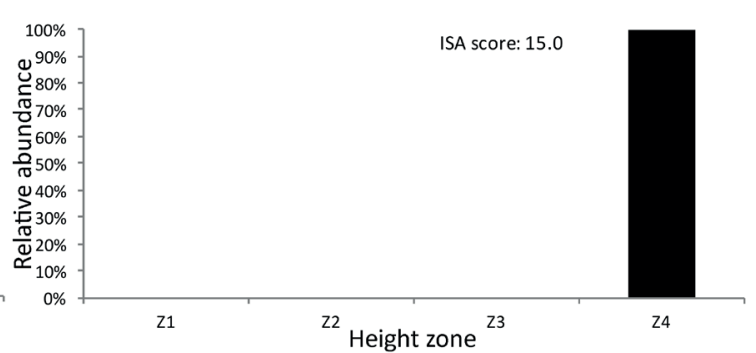

Figure 6. The relative abundance of individuals of each of the specialist species per height zone in Michelin Ecological Reserve. 
About $70 \%$ of the bryophyte species grew as mats (Fig. 7). Species with this life form occurred on all trees and in all height zones. Each of the other life forms represented less than $10 \%$ of the species. The number of dendrois, pendents and crusts did not vary significantly among zones, while cushions were restricted to zones 2 and 3, and wefts were significantly more abundant in zone 1 .
Among the morphological features that can be related to water retention and/or water conduction, lobules and papillae did not vary significatively among height zone. Long acuminate leaf apex, concave leaf shape and well developed alar cells were present more in zone 1 , while hyalocysts and tomentose were present more on the higher strata- zones 3 and 4 (Fig. 8).

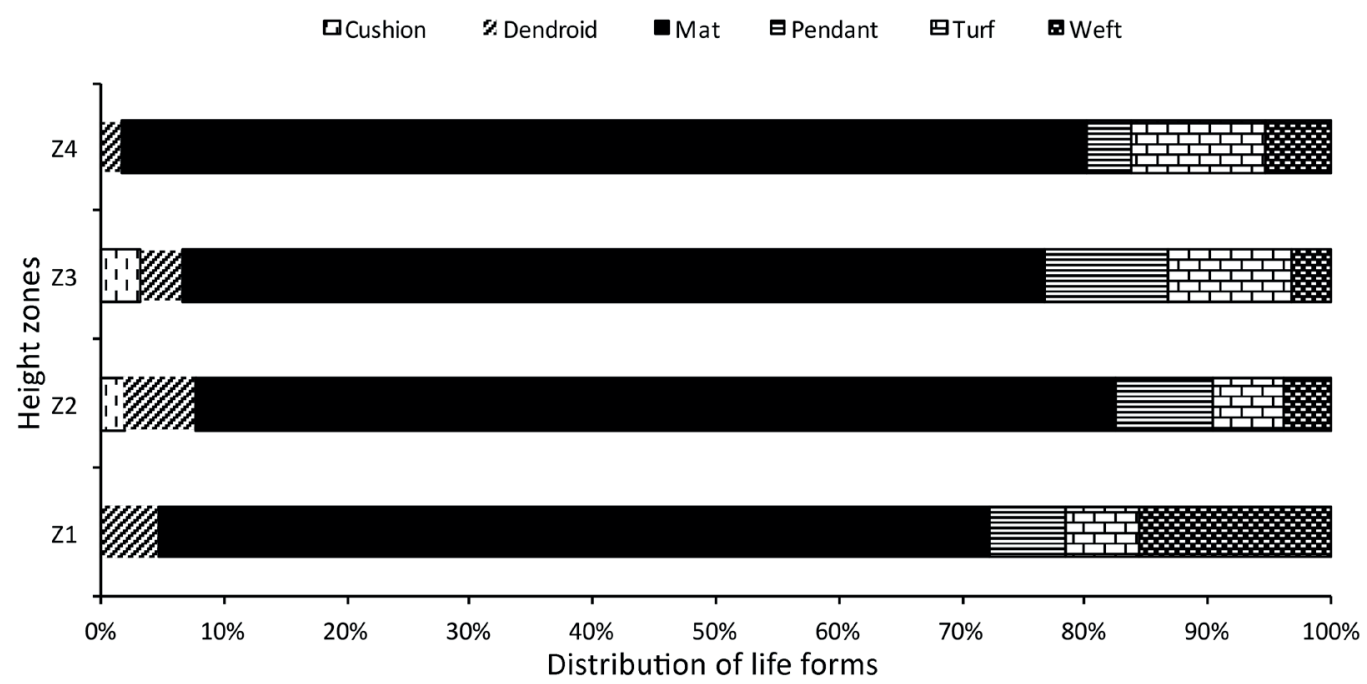

Figure 7. Distribution of life forms along the vertical gradient.

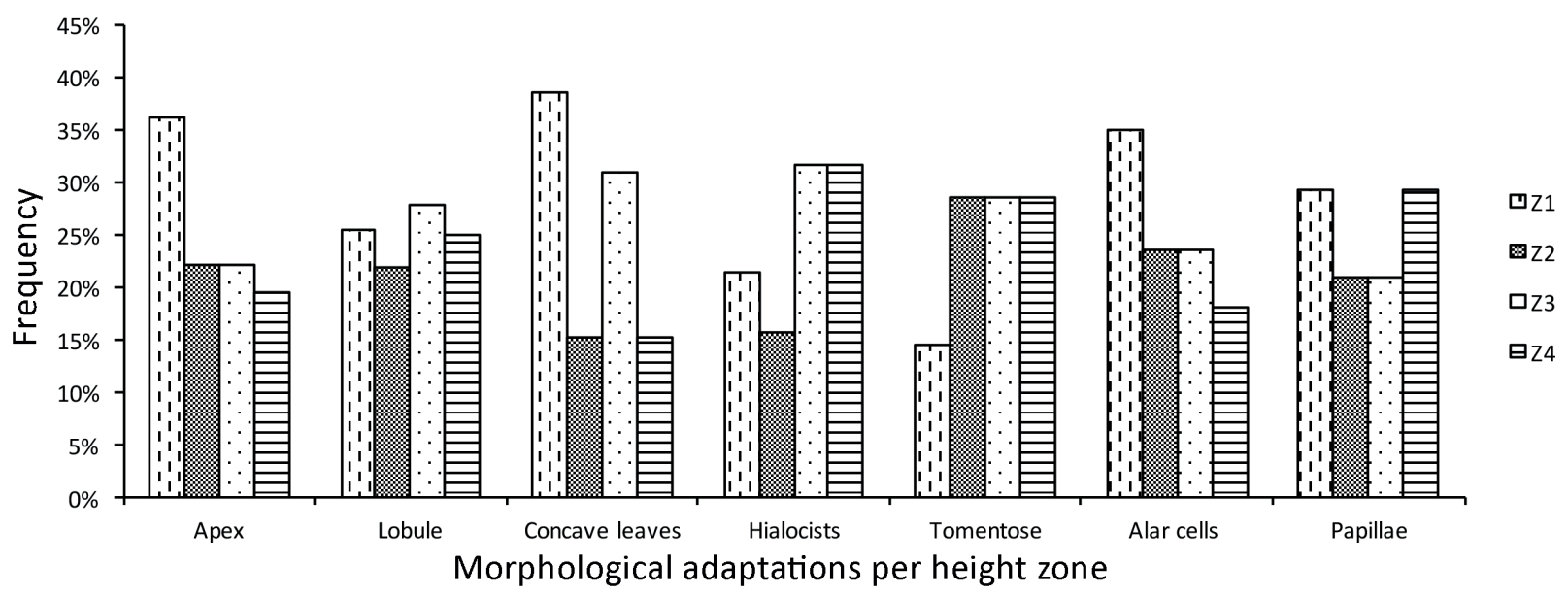

Figure 8. Distribution of morphological adaptations for water retention and/or conduction along the vertical gradient.

\section{Discussion}

The distribution of bryophytes among height zones and understory exhibited a well-known pattern for tropical rain forests; liverworts were more frequent than mosses in all height zones, both in number of species and in abundance, and mosses were mainly concentrated in the understory (Gradstein \& Culmsee 2010). The dominance of liverworts was due to the high number of species of Lejeuneaceae, which represented $44 \%$ of the total number of species. Lejeuneaceae can represent up to $70 \%$ of the bryoflora of a tropical rainforest (Cornelissen \& Gradstein 1990; Gradstein et al. 1990), and, together with Plagiochillaceae, comprise the most important pantropical families of liverworts in terms of number of species (Gradstein et al. 2001; Holz et al. 2002). 
The samples from the understory included $77 \%$ of all species of bryophytes sampled. This result is in agreement with other studies carried out in the Atlantic Forest, where the turnover of species along the vertical gradient is absent or not pronounced (Germano 2003; Campelo \& Pôrto 2007; Alvarenga et al. 2009). Although species zonation along the vertical gradient was not very clear, the changes observed from zone 1 to zone 4 were statistically significant. This differs from what has been found in other studies in the Atlantic Forest in the Northeast Region of Brazil, where no significant differences in species composition along the vertical gradient were found. Generally, the lack of zonation in tropical forests is thought to be related to homogeinization of environmental conditions due to forest fragmentation, fragment isolation and forest exploitation, which changes forest structure by creating openings and therefore decreasing moisture and shade (Alvarenga et al. 2009). Such alteration allows canopy species to colonize lower strata of the forest and hampers the occurrence of several understory species. The mechanisms that influence species establishment in specific microhabitats are, mostly, physiological (Glime 2007). Shade especialists are innibited by long periods of exposure to light and are frequently limited to the understory of a forest, sheltered by the canopy cover of individual trees. Therefore, shade specialists tend experience a drastic reduction in abundance with forest fragmentation (Alvarenga \& Pôrto 2007) or disapear altogether after deforestation (Costa 1999; Acebey et al. 2003). Indeed, species classified as shade specialists in this study (zones 1 and 2 indicators) are commonly found in the undersory of other tropical forests and hardly ever in the canopy (Montfoort \& Ek 1990; Acebey et al. 2003; Campelo \& Pôrto 2007). On the other hand, some species require high levels of solar radiation, such as some highly pigmented species in the families Frullaniaceae and Orthotrichaceae (Glime 2007). Species of Frullania are particularly tolerant to dissecation (Romero et al. 2006) and are comonly found in the higher zones of trees, and especially in the outer canopy, as we have found in our study with Frullania caulisequa and Groutiella apiculata, being among the few species classified as zone 4 indicators (sun specialists).

The percentage of species classified as specialists according to ISA (8\%, $10 \mathrm{spp}$.) is much lower than what was found in a similar study of epiphytic bryophytes in the Guianas, where 96 species, corresponding to $66 \%$ of the species found, were classified as specialists (Oliveira et al. 2009). The low percentage of specialists in the present study might be indicative of a high degree of disturbance to the reserve. Because bryophytes are sensitive to changes in the microclimate, habitat fragmentation can negatively affect species richness and composition and increase the representation of generalist species and diminish both sun and shade specialists (Alvarenga \& Pôrto 2007). According to Werneck \& Espírito-Santo (2002), the closed canopy of undisturbed forests is more favorable for the establishment of a vertical species turnover of epiphytes, because microenvironmental conditions are more distinct.

The predominant life form found in our study (mats), is in agreement with what has been documented in other tropical forests (Cornelissen \& Steege 1989; Montfoort \& Ek 1990; Costa 1999; Pardow et al. 2012). It is widely accepted that life forms reflect habitat characteristics, and are closely related to moisture availability (Pócs 1982; Thiers 1988; Proctor 1990). Life forms such as mats or wefts have a high capacity for water retention, and grow strongly appressed to the surface of the substrate (Glime 2007). They are abundant growing along trunks in tropical secondary forests, which have high levels of humidity and light (Sillet et al. 1995), as was recorded in the present study.

Life form classifications are based on morphological characters, and so those structures that seem to be adaptations to water conduction and retention can be used as indicators of environmental conditions (Frahm 2003). The higher frequency of occurrence of some of these morphological adaptations in certain height zones at Michelin ecological reserve reflects the microenvironmental gradient along tree trunks. The predominance of leaves with a long acuminate apex in lower zones, as well as concave leaves and well developed allar cells, was expected since these are typical of understory families like Calymperaceae, Pylaisiadelphaceae and Sematophyllaceae. Among the other morphological characteristics investigated, lobules are present in almost all Lejeuneaceae, which were distributed throughout the entire height gradient with no tendency for preference to a specific height zone. Likewise, papillae were abundant in all zones and revealed no pattern of altitudinal distribution, as was also found in a study of altitudinal zonation in Borneo (Frey et al. 1990). Until now, lobules and papillae had been successfully used as indicators of environmental conditions in altitudinal zonation, such as in a study in Central Africa (Kürschner \& Seifert 1995). Adaptation to water retention and conduction along the vertical gradient in tropical forests needs further study.

We verified that there is substitution of species of epiphytic bryophytes along the height zones of host trees, however, this zonation is relatively weak in comparison with the results usually found in tropical forest environments. The morphological adaptations for water conduction or retention, as well as life forms, are strongly associated with microhabitat. A better understanding of the spatial distribution of these organisms in Atlantic Forest fragments is essential, since bryophytes have important roles in the proper functioning of ecosystems and can serve as bioindicators for monitoring changes in biodiversity, be they natural or caused by human actions.

\section{Acknowledgements}

The authors thank Dr. P.E.A.S. Câmara, of the University of Brasília (UnB), Brazil, for confirmation of the Taxithelium 
species identifications and Dr. H. ter Steege for comments on data analysis.

\section{References}

Acebey C, Gradstein SR, Krömer T. 2003. Species richness and habitat diversification of bryophytes in submontane rain forest and fallows in Bolivia. Journal of Tropical Ecology 18: 1-16.

Alvarenga LDP, Pôrto KC. 2007. Patch size and isolation effects on epiphytic and epiphyllous bryophytes in the fragmented Brazilian Atlantic forest. Biological Conservation 134: 415-427.

Alvarenga LDP, Pôrto KC, Silva MPP. 2009. Relations between regional-local habitat loss and metapopulation properties of epiphyllous bryophytes in the Brazilian Atlantic Forest. Biotropica 41: 682-691.

Buck WR. 1998. Pleurocarpous mosses of the West Indies. Memoirs of the New York Botanical Garden 82: 1-400.

Campelo MJA, Pôrto KC. 2007. Brioflora epífita e epífila da RPPN Frei Caneca, Jaqueira, PE, Brasil. Acta Botanica Brasilica 21: 185-192.

CEI/CONDER - Centro de Estatística e Informação/Companhia do Desenvolvimento da Região Metropolitana de Salvador. 1993. Informações básicas dos municípios baianos: Região Litoral Sul. Salvador, Secretaria do Planejamento, Ciência e Tecnologia.

Cornelissen JHC, Gradstein SR. 1990. On the occurrence of Bryophytes and macrolichens in different lowland rain fo rest types at Mabura Hill, Guyana. Tropical Bryology 3: 29-35.

Cornelissen JHC, Steege H. 1989. Distribution and ecology of epiphytic bryophytes and lichens in dry evergreen forest of Guyana. Journal of Tropical Ecology 5: 131-150.

Costa DP. 1999. Epiphytic bryophyte diversity in primary and secondary lowland rainforests in southeastern Brazil. Bryologist 102: 320-326.

Crandall-Stotler B, Stotler RE, Long DG. 2009. Phylogeny and classification of the Marchantiophyta. Edinburgh Journal of Botany 66: 155-198.

Dauphin G. 2003. Ceratolejeunea. Flora Neotropica Monograph 90: 1-86.

Florschütz PA. 1964. The Mosses of Suriname. Leiden, E. J. Brill.

Frahm JP. 2003. Manual of Tropical Bryology. Tropical Bryology 23: 1-195.

Frey W, Gossow R, Kürschner H. 1990. Verteilungsmuster von Lebensformen, wasserleitenden und wasserspeichernden Strukturen in epiphytischen Moosgesellschaften am Mt. Kinabalu (Nord Borneo). Nova Hedwigia 51: 87-119

Fulford MH. 1963. Manual of the leafy Hepaticae of Latin America I. Memoirs of the New York Botanical Garden 11: 1-172.

Fulford MH. 1966. Manual of the leafy Hepaticae of Latin America II. Memoirs of the New York Botanical Garden 11: 173-276.

Fulford MH. 1968. Manual of the leafy Hepaticae of Latin America III. Memoirs of the New York Botanical Garden 11: 277-392.

Fulford MH. 1976. Manual of the leafy Hepaticae of Latin America IV. Memoirs of the New York Botanical Garden 11: 393-535.

Germano SR. 2003. Florística e Ecologia das Comunidades de Briófitas em um Remanescente de Floresta Atlântica (Reserva Ecológica do Grajaú, Pernambuco, Brasil). PhD Thesis, Universidade Federal de Pernambuco, Brazil.

Gimingham CH, Birse EM. 1957. Ecological studies on growth-form in bryophytes: I. Correlations between growth-form and habitat. Journal of ecology 45: 533-545.

Glime JM. 2007. Economic and ethnic uses of bryophytes. In: Flora of North America Editorial Committee. (Eds.). Flora of North America and North of Mexico. Oxford, Oxford University Press. p. 14-41.

Goffinet B, Buck WR, Shaw AJ. 2009. Morphology and classification of the Bryophyta. In: Goffinet B, Shaw AJ. Bryophyte Biology 2: 55-138.

Gradstein SR, Costa DP. 2003. The Hepaticae and Anthocerotae of Brazil. Memoirs of the New York Botanical Garden 87: 1-318.

Gradstein SR, Culmsee H. 2010. Bryophyte diversity on tree trunks in montane forests of Central Sulawesi, Indonesia. Tropical Bryology 31: 95-105.
Gradstein SR, Griffin D, Morales MI, Nadkarni NM. 2001. Diversity and habitat differentiation of mosses and liverworts in the cloud forest of Monteverde, Costa Rica. Caldasia 23: 203-212.

Gradstein SR, Hietz P, Lücking R, et al.1996. How to sample the epiphytic diversity of tropical rain forests? Ecotropica 2: 59-72.

Gradstein SR, Homeier J, Gansert D. 2008. The Tropical Mountain Forest, patterns and processes in a biodiversity hotspot. Göttingen, Göttingen University Press.

Gradstein SR, Montfoort D, Cornelissen JHC. 1990. Species richness and phytogeography of the bryophyte flora of the Guianas, with special reference to the lowland forest. Tropical Bryology 2: 117-126.

Holz I, Gradstein SR, Heinrichs J, Kappelle M. 2002. Bryophyte diversity, microhabitat differentiation and distribution of life forms in Costa Rican upper montane Quercus forest. Bryologist 105: 334-348.

Kürschner H, Seifert UH. 1995. Wissenschaftliche Ergebnisse der BRYOTROP Expedition nach Zaire und Rwanda 6. Lebensformen und adaptationen zur wasserleitung und wasserspeicherung in epiphytischen moosgesellschaften im östlichen Kongobecken. Tropical Bryology 11: 87-118.

Lowman MD, Rinker HB. 2004. Forest canopies. Oxford, Elsevier Academic Press.

Mccune B, Grace JB. 2002. Analysis of ecological communities. Gleneden Beach, MjM Software Design.

Montfoort D, Ek RC. 1990. Vertical distribution and ecology of epiphytic Bryophytes and lichens in a lowland rain forest in French Guiana. MSc Thsis, University of Utrecht, The Netherlands.

Oliveira SM, Steege H, Cornelissen JHC, Gradstein SR. 2009. Niche assembly of epiphytic bryophyte communities in the Guianas: A regional approach. Journal of Biogeography 36: 2076-2084.

Pardow A, Gehrig-Downie C, Gradstein SR, Lakatos M. 2012. Functional diversity of epiphytes in two tropical lowland rainforests, French Guiana: using bryophyte life-forms to detect areas of high biodiversity. Biodiversity and Conservation 21: 3637-3655.

Pócs T. 1982. Tropical forest bryophytes. In: Smith AJE. (ed.) Bryophyte Ecology. London, Chapman and Hall. p. 59-104.

Proctor MCF. 1990. The physiological basis of bryophyte production. Botanical Journal of the Linnean Society 104: 61-77.

R Core Team. 2012. R: A language and environment for statistical computing. R Foundation for Statistical Computing, Vienna, Austria. ISBN 3-900051-07-0, http://www.R-project.org/. 19 Nov. 2012.

Richards PW. 1984. The ecology of tropical forest bryophytes. In: Schuster RM. (ed.) New manual of Bryology. Nichinan, Hattori Botanical Laboratory. p. 1233-1270.

Romero C, Putz FE, Kitajima K. 2006. Ecophysiology in relation to exposure of pendant epiphytic bryophytes in the canopy of a tropical montane oak forest. Biotropica 38: 35-41.

Sharp AJ, Crum H, Eckel PM. 1994. The moss flora of Mexico. Memoirs of the New York Botanical Garden 69: 1-1113.

Sillet C, Gradstein SR, Griffin D. 1995. Bryophyte diversity of Ficus tree crowns from cloud forest and pasture in Costa Rica. Bryologist 25: 1-260.

Silva MPP, Pôrto KC. 2013. Bryophyte communities along horizontal and vertical gradients in a human-modified Atlantic forest remnant. Botany 91: 155-166.

Sporn SG, Bos MM, Kessler M, Gradstein SR. 2010. Vertical distribution of epiphytic bryophytes in an Indonesian rainforest. Biodiversity and Conservation 19: 745-760.

Thiers BM. 1988. Morphological adaptations of the Jungermanniales (Hepaticae) to the tropical rain forest habitat. Journal of the Hattori Botanical Laboratory 64: 5-14.

Veloso HP, Rangel Filho ALR, Lima JC. 1991. Classificação da vegetação brasileira, adaptada a um sistema universal. Rio de Janeiro, IBGE.

Werneck MS, Epírito-Santo MM. 2002. Species diversity and abundance of vascular epiphytes on Vellozia piresiana in Brazil. Biotropica 34: 51-57.

Whitmore TC. 1998. An introduction to Tropical Rain Forests. New York, Oxford University Press. 